\title{
Progress towards the comprehensive control of hepatitis B in Africa: a view from South Africa
}

\author{
M C Kew
}

\begin{abstract}
The carrier rate of hepatitis $B$ virus (HBV) in black Africans averages $10.4 \%$ throughout the continent. Even within each country, however, there may be wide variations. HBV carriage in black Africans is largely established in early childhood, mostly through horizontal transmission. Perinatal transmission also occurs but to a much lesser extent than in the Far East. For unknown reasons, HBeAg positivity rates are much lower in black Africans of childbearing age than in women in the Far East. Universal HBV vaccination of infants in South Africa started in April 1995. Effective integration into the Expanded Programme on Vaccination will probably be necessary if administration of second and third doses is to be ensured. Fortunately, a natural process of urbanisation is also having a beneficial effect on the black carrier rate in South Africa, as urban carrier rates tend to be much lower than those in rural area. Within the next 20 years, therefore, there should be a great reduction in the numbers of acute HBV infections and new carriers. However, it will take much longer before there is any substantial impact on the burden of the longterm sequelae of $\mathrm{HBV}$ infection - that is, cirrhosis and hepatocellular carcinoma.

(Gut 1996; 38 (suppl 2): S31-S36)
\end{abstract}

Keywords: hepatitis B, Africa, carrier rates, horizontal transmission, vaccination.

\section{Epidemiology}

PREVALENCE

Although data on the prevalence of hepatitis B virus (HBV) infection in Africa are neither complete nor always accurate, $\mathrm{HBV}$ infection is undoubtedly highly endemic in sub-Saharan Africa. As many as $98 \%$ of the approximately 470 million inhabitants of Africa are infected with this virus at some time during their lives and about $10 \%$ remain infected. ${ }^{1} \mathrm{HBV}$ induced diseases, especially hepatocellular carcinoma, cause more than 230000 deaths in Africans each year. ${ }^{1}$ Some 33 million black people live in South Africa, of whom approximately 3.3 million are chronically infected with HBV. The remainder of the South African population comprises white people (about $5 \cdot 2$ million), Eur-Africans (mixed descent, about

3.8 million), and Asians (about 1 million, including some 20000 Chinese originating from mainland China or Taiwan).

HBV carrier rates in black Africans range from $5.7 \%$ in Morocco in north Africa to $19 \%$ in Niger in west Africa (Table). ${ }^{1}$ The average frequency throughout the continent is $10.4 \%$, although isolated pockets have prevalences up to $35 \%$ or higher. Lifelong HBV exposure rates vary from $61 \%$ in Liberia in west Africa and Kenya in east Africa to $98 \%$ in Namibia in southern Africa, with an average of $77 \%$ (Table). ${ }^{1}$ Carrier rates may differ between tribes in a single country: for example, in Nigeria prevalences range from $2.9 \%$ in the Nupe to $21.4 \%$ in the Gwari tribe. ${ }^{2}$ Frequency of infection may even vary between villages: in Manduar in The Gambia, $62 \%$ of children aged 2-4 years are infected, whereas the corresponding figure in neighbouring Keneba is only $27 \%{ }^{3}$ Similarly, in KaNgwane in South Africa the hepatitis B surface antigen (HBsAg) positivity rate in pregnant black women is as low as $1.7 \%$ in Legogote or as high as $14.3 \%$ in Boschfontein. ${ }^{4}$

Development of persistent $\mathrm{HBV}$ infection seems to be determined by host immune response rather than variations in the virulence of the virus. Variations in immune response are often linked to polymorphism of the major histocompatibility complex (MHC), and Thursz et al have recently shown that the MHC class II allele $\mathrm{DRB} 1^{\star} 1302$ is associated with protection against persistent $\mathrm{HBV}$ infection among both children and adults in The Gambia. ${ }^{5}$

Rural black populations in southern Africa have HBV carrier rates of $9 \cdot 6-14 \%$ and total exposure rates of $76-98 \% .{ }^{46}$ In an analysis of a large cohort of rural black males from different parts of the sub-continent (employed on a short-term basis in the South African gold

Summary of hepatitis $B$ virus infection in $A$ frica

\begin{tabular}{lll}
\hline & Carrier rate (\%) & Total exposure (\%) \\
\hline North Africa & & \\
Tunisia & $6 \cdot 5$ & $60-64$ \\
Morocco & $5 \cdot 7$ & NA \\
West Africa & & $90-92$ \\
Senegal & $13 \cdot 6-14 \cdot 7$ & 96 \\
Mali & $17 \cdot 6$ & 82 \\
Niger & $19 \cdot 0$ & 61 \\
Liberia & $7 \cdot 6$ & $57-75$ \\
Nigeria & $8 \cdot 9-13 \cdot 6$ & $67-76$ \\
East Africa & & 75 \\
Ethiopia & $6 \cdot 2-9 \cdot 9$ & 61 \\
Burundi & $12 \cdot 0$ & NA \\
Kenya & $7 \cdot 0-12 \cdot 2$ & \\
Tanzania & $8 \cdot 6$ & NA \\
Central Africa & $9 \cdot 2$ & $84-98$ \\
Zaire & & 74 \\
Southern Africa & $11.6-13.6$ & 62 \\
Namibia & $8 \cdot 3$ & \\
KaNgwane & $7 \cdot 5$ & \\
Zambia & & \\
\hline
\end{tabular}

$\mathrm{NA}=$ not available.

\footnotetext{
Correspondence to: Dr M C Kew, Department of Medicine, University of the Witwatersrand, Johannesburg, 7 York Road Parktown, 2193 South Parkica.

Medical Research Hepatology Research Baragwanath Johannesburg, South Africa

MC Kew
} 
mining industry), the prevalence of $\mathrm{HBsAg}$ ranged from $5 \cdot 5 \%$ to $14 \%{ }^{7} \mathrm{HBV}$ causes $50-70 \%$ of the nearly three million cases of acute viral hepatitis that occur in black Africans each year. ${ }^{8}$ In black South Africans, acute hepatitis A and hepatitis B are equally common in the first decade of life; thereafter, HBV accounts for $65 \%$ of cases of acute hepatitis. ${ }^{9}$

Hepatocellular carcinoma occurs commonly in black Africans living to the south of the Sahara desert. ${ }^{1}$ The tumour is especially prevalent in southern Africa, where annual age adjusted incidences of 113.9 per 100000 of the population have been recorded in Mozambican Shangaans, 60 per 100000 in Zimbabwe, and 29 per 100000 in South Africa's black population. ${ }^{1} \mathrm{HBV}$ is estimated to cause at least two thirds of all hepatocellular carcinomas occurring in sub-Saharan Africa. Cirrhosis is another important sequela of chronic HBV infection in Africa. About $20 \%$ of cirrhosis in black Africans is believed to arise in this way.

\section{SEX DISTRIBUTION}

Lifetime exposure rates to $\mathrm{HBV}$ in black Africans are similar in the two sexes. ${ }^{1}$ Despite this, HBV carriage is almost always more common in men, with ratios ranging from $1 \cdot 1: 1$ to $3 \cdot 2: 1$ (although figures of $1 \cdot 4-2 \cdot 5: 1$ are usual). ${ }^{1}$ In southern Africa, ratios for HBsAg positivity vary from $1 \cdot 5: 1$ to $3 \cdot 2: 1.4610$

\section{RURAL-URBAN DIFFERENCES}

Information about rural-urban differences in HBV prevalence is available from few African countries. In Senegal, no rural-urban difference in frequency of $\mathrm{HBV}$ infection is evident (with reported carrier rates of $12 \%$ and $13.8 \%$ and total exposures of $87 \%$ and $92 \cdot 7 \%$, respectively). ${ }^{11}$ However, differences do occur in both Kenya and southern Africa. In Nairobi, capital city of Kenya, the carrier rate is $5.3 \%$ compared with $12 \%$ in rural Kenyans. ${ }^{12} \mathrm{~A}$ similar difference is described along the east coast of South Africa: chronic HBV infection is present in $15.5 \%$ of a rural population in the Transkei but in only $7 \cdot 4 \%$ of the urban black population living in Durban. ${ }^{13}$ Even more striking is the discrepancy between the prevalence in Soweto, the largest black city in South Africa, and that in rural areas of the subcontinent. For example, in Ovamboland, situated in the north of Namibia, $17 \%$ of men and $11 \%$ of women are positive for $\mathrm{HBsAg} .{ }^{6}$ In contrast, the frequency in women of similar age born and living in Soweto is only $1.3 \% .{ }^{14}$ An analysis of black children in Ovamboland showed $15 \%$ to be carriers of the virus by the age of 3-4 years, with a total exposure rate of $34 \%$ at 13 years. $^{6}$ By comparison, the prevalence of carriers in Sowetan residents is only $1.1 \%$ at the age of 13 years and $1.4 \%$ at 19 years, with total exposure rates at these times of $9.2 \%$ and $23.9 \%$ respectively. ${ }^{10}$ The carrier rate is $1.3 \%$ in women born and living in Soweto, compared with $4 \%$ in those born in rural areas but later moving to Soweto, with total exposures of $35 \cdot 2 \%$ and $44 \cdot 7 \%$, respectively. ${ }^{14}$

\section{AGE OF ONSET OF CARRIER STATE}

HBV carriage in black Africans is largely established in early childhood. In contrast with the Far East, where maternal-infant perinatal transmission is the predominant route of early infection, most black children are infected as a result of 'horizontal' spread. The major sources of $\mathrm{HBV}$ at this age are highly infectious siblings less than 5 years of age and, to a lesser extent, other family members and unrelated young playmates. ${ }^{3} 15$ Perinatal infection does occur, ${ }^{6}$ but to a much lesser extent than in the Far East. ${ }^{16}$ Nevertheless, those black children who are born to replicative carrier mothers are at very high risk: in Ovamboland $65 \%$ and in Senegal $66.7 \%$ of babies born to $\mathrm{HBsAg} /$ HBeAg positive mothers become carriers. ${ }^{6} 15$ This risk is thus substantially the same as that in the Far East. ${ }^{16}$ However, far fewer black than Asian HBV carriers of childbearing age have replicative infection: $\mathrm{HBeAg}$ positivity rates among pregnant $\mathrm{HBV}$ carriers are $18.6 \%$ in Senegal and Burundi, ${ }^{11} 15 \%$ in Namibia, ${ }^{6}$ $10.3 \%$ in KaNgwane, ${ }^{4} 12 \%$ in rural born women living in Soweto, ${ }^{14}$ and $0 \%$ in urban born women living in Soweto, ${ }^{14}$ compared with figures of $40 \%$ or more in the Far East. ${ }^{16}$ Why the replicative phase of chronic HBV infection persists far longer in Asian than in black carriers is uncertain. A genetic component seems likely because Chinese women who have emigrated to South Africa from China or Taiwan retain their original $\mathrm{HBeAg}$ pattern even after several generations in the new environment: during their reproductive years, they have $\mathrm{HBeAg}$ positivity rates of around $40 \%$, and perinatal maternal-infant infection is common. ${ }^{17}$

The first (and largest) wave of $\mathrm{HBV}$ infection in black Africans begins during the latter half of the first year of life and high carrier rates are already present by the age of 3-5 years. ${ }^{34615} \mathrm{~A}$ further small peak occurs at entry into school, and another at the commencement of sexual activity. This general pattern is similar to that in the Far East.

RACE

Other racial groups living in Africa have much lower HBV infection rates than do blacks. In this regard, the most complete information comes from South Africa. In this country, white subjects have a carrier rate of only $0 \cdot 2 \%$ and a total exposure rate of approximately $5 \%, 18$ and Eur-Africans have frequencies intermediate between those in black people and white people (carriage of $0.4-3 \%$ and total exposure of 18-25\%). ${ }^{19}$ Indians living in South Africa have the same low rate of $\mathrm{HBV}$ infection as white people. The South African Chinese community has a carrier rate of $5.3 \%$ and a total exposure rate of $50 \% .^{17}$

\section{ROUTES OF TRANSMISSION}

The vast majority of black African carriers of HBV are infected in early childhood, predominantly by horizontal transmission. 34615 Other family members, particularly highly infectious 
siblings aged between 1 and 5 years, and unrelated playmates of the same age, are the main sources of infection. ${ }^{315}$ Maternal-infant perinatal infection plays a relatively minor part in black Africans. ${ }^{34615}$

The precise ways in which horizontal spread of the virus take place, and the relative importance of each, remain uncertain. Bites from bloodsucking insects, such as mosquitoes and bed bugs, and scarification of the skin by witch doctors (during ritual initiation ceremonies or when giving treatment) are suspected to play a role, in part because they are far more likely to occur in a rural than in an urban setting. No proof for the former is available, although there is some epidemiological support for a role for scarification. ${ }^{20}$

Socioeconomic differences in themselves do not seem to be crucial in determining the high early carrier rates in black Africans because, in an analysis of Sowetan children, no obvious differences in infection rates were found between the highest and the lowest socioeconomic classes. ${ }^{10}$ Studies performed among people attending clinics for sexually transmitted diseases confirm the importance of sexual transmission among black and white adults. ${ }^{21}$

\section{IMPACT OF VACCINATION AND OTHER}

CONTROL POLICIES

In 1994, universal immunisation against HBV was included among the new health initiatives of the first democratically elected South African government. Vaccination of all newborn babies and infants under the age of 1 year started in April 1995. Clearly, this programme cannot yet have made any impact on the high prevalence of HBV infection in the black population of South Africa. One of the overriding reasons for the very tardy start to universal vaccination against $\mathrm{HBV}$ was a lack of money, which resulted from a severely depressed national economy that was, in turn, largely consequent upon the political policies of the apartheid regime. Another was the high cost of the vaccines available in South Africa at the time that many other countries were starting to immunise on a large scale. Even now, at 2.95 rands per dose, $\mathrm{HBV}$ vaccine accounts for $42 \%$ of the total cost of vaccination in South Africa. Vaccines (initially plasma derived, later recombinant DNA) have, however, been readily available for some years in the private sector and many high risk people (mainly health care workers) were immunised at their own expense.

The HBV vaccine that is being given, free of charge, to all children under the age of 1 year is a plasma derived flash heated vaccine (Hepaccine-B). The dose is $1.5 \mu \mathrm{g}$ to be given by intramuscular injection, and newborns will receive the vaccine at 6,10 , and 14 weeks of age to coincide with existing clinic visits. Additional doses will not be given, and no 'catch up' injections or programme for routine vaccination of older age groups are planned. Concern has been expressed from a number of sources over the small dose of vaccine to be used, and this aspect will need to be evaluated after suitable intervals. There is also a possibility that low doses will encourage the emergence of antibody escape mutants, and it is planned also to investigate this possibility.

Apart from one early trial in newborn black Africans, begun in 1980 to test the immunogenicity of the newly available plasma derived vaccine and to determine if maternal antibodies interfere with immunisation, ${ }^{22}$ only one limited vaccination programme had been performed in South Africa before $1994 .^{23}$ This involved the use of a gift of plasma derived vaccine (HeptaVax) by Merck, Sharp and Dohme. Sufficient $10 \mu \mathrm{g}$ doses were provided to vaccinate the 1989 birth cohort (21000 babies) in Venda, a rural region in the northern Transvaal. Apart from supplying a much needed source of vaccine, this exercise highlighted some of the important shortcomings of vaccination programmes in 'field conditions' in rural parts of Africa when they are carried out without the financial and logistic support that the programme in The Gambia enjoys. The most worrying was a substantial 'drop off' in receipt of the second dose of the vaccine (to $53 \%$ ) and, even more so, the third dose (to $39 \%)$. Clearly, HBV vaccination will have to be effectively integrated into the Expanded Programme on Immunisation if this highly unsatisfactory result is to be avoided in rural Africa as a whole.

From the data available on the prevalences of chronic HBV infection in rural and urban black people, it is evident that a natural process, namely, urbanisation, is having a beneficial effect on the black carrier rate in South Africa. The decrease in the carrier rate that accompanies urbanisation ${ }^{14}$ results from the relative infrequency of perinatal infection and the very high rate of horizontal infection of babies and young children in rural areas of southern Africa. Children born and growing up away from the large pool of highly infectious young siblings and playmates present in rural areas have far lower carrier rates. Lower carrier rates in urban black people are paralleled by lower incidences of hepatocellular carcinoma. ${ }^{24}$

By enforcing strict racial segregation over many years, the policy of apartheid protected the minority white population against infection from the large numbers of black HBV carriers.

BURDEN OF DISEASE FOR THE NEXT 20 YEARS Based on the very encouraging results already achieved by the longest running vaccination programmes in the Far East and Africa, ${ }^{25}$ the present practice in South Africa of vaccinating all newborn babies and infants under the age of 1 year, to be superceded in time by the inclusion of HBV vaccination in the Expanded Programme on Immunisation, together with continuing (and increasing) urbanisation of the rural black population, should have the desired effect of greatly reducing the numbers of both HBV carriers and acute HBV infections in the population within the next 20 years. There 
will, however, be little impact during this time on the burden of the longterm sequelae of HBV infection - hepatocellular carcinoma and cirrhosis. A substantial decline in the incidence of these diseases will take far longer - probably 50 or 60 years. As HBV related hepatocellular carcinoma and, to a lesser extent, HBV related cirrhosis are important health problems throughout sub-Saharan Africa, the major burden of life threatening HBV related diseases will not decrease appreciably in the next 20 years.

COINFECTION WITH OTHER VIRUSES (HCV, HDV, HIV)

Although little information on the epidemiology of hepatitis delta virus (HDV) infection in Africa is available, its prevalence seems to vary greatly in different parts of the continent despite the universally high prevalence of $\mathrm{HBV}$ infection. In Senegal, antibody to this virus was detected in $21 \%$ of HBV carriers. ${ }^{26}$ Few HBV carriers are anti-HDV positive in the southern provinces of Kenya, whereas $31 \%$ are positive in the northern provinces. ${ }^{27} \mathrm{HDV}$ infection is rare in Ethiopia ${ }^{28}$ and southern Africa. ${ }^{729}$ No cases of coinfection with HBV and HDV were found in a series of southern African black people with hepatocellular carcinoma or in matched controls. ${ }^{29}$

There is, at present, limited information on the epidemiology of hepatitis $\mathrm{C}$ virus (HCV) infection in Africa and virtually no information on coinfection with HBV and HCV. Reported prevalences of the HCV carrier state are $0.7 \%$ in some rural southern African populations, ${ }^{30}$ $1.2 \%$ in urban blood donors in South Africa, ${ }^{31}$ $4.2 \%$ in asymptomatic adults in Tunisia/ Burundi, $325 \%$ in adults in Cameroon, ${ }^{32}$ $2 \cdot 2 \%$ in asymptomatic adults in Senegal, ${ }^{32}$ and between 10.9 and $24.3 \%$ in Egypt. ${ }^{33} 34$ These prevalences were mainly obtained with first generation enzyme assays, which were prone to both false-positive and false-negative results. More accurate figures using second and third generation assays, confirmed by recombinant immunoblot assays or the use of the polymerase chain reaction to detect $\mathrm{HCV}$ cDNA, are needed. Using these methods, about $5 \%$ of southern African blacks with hepatocellular carcinoma are coinfected with $\mathrm{HBV}$ and HCV. ${ }^{35}$

Analysis of $\mathrm{HCV}$ genotypes has shown that type 5 is specific to South Africa. ${ }^{36}$ More than $50 \%$ of HCVs isolated in South Africa thus far have been of this subtype. ${ }^{36}$ A few type 4, which is the predominant genotype in Africa, have also been detected. ${ }^{36}$

The prevalence of HIV in Africa varies enormously, although the virus is hyperendemic in most African countries. Details of rates of coinfection between $\mathrm{HBV}$ and HIV in the general population are scanty. The frequency with which HBV and HIV coexist in black Africans with hepatocellular carcinoma is presently under investigation, but the preliminary evidence does not support a significant role for HIV in the pathogenesis of this tumour.
PROPORTION OF CHRONIC CARRIERS WHO ARE HBeAg POSITIVE

Comparatively few black Africans who are carriers of HBV still have replicative infection by the time they reach adulthood. In Senegal and Burundi, $\mathrm{HBeAg}$ is detected in only $13.3 \%$ of $\mathrm{HBsAg}$ positive men and in $18.6 \%$ of $\mathrm{HBsAg}$ positive pregnant women, ${ }^{11}$ in Namibia in $15 \%$ of women, ${ }^{6}$ and in South Africa in $5-16 \%$ of men and $10.3 \%$ of women. ${ }^{4} 1437$ About one third of black Africans with HBV related hepatocellular carcinoma are $\mathrm{HBeAg}$ positive. ${ }^{38}$

\section{IMPORTANCE/PREVALENCE OF PRECORE MUTANT DISEASE}

Little is known about the prevalence or importance of precore mutants in Africa. In one study, three Moroccan and one Ethiopian $\mathrm{HBeAg}$ negative carriers were shown to have a $\mathrm{G}$ to A mutation, introducing a stop codon at nucleotide position $1896 .^{39}$ Two of the patients also had a $\mathrm{G}$ to $\mathrm{A}$ transversion at position 1899.

\section{DEVELOPED VERSUS DEVELOPING WORLD PERSPECTIVES}

South Africa is a mixture of First and Third Worlds. Much of the black African population can be regarded at present as belonging to the Third World, whereas the white population largely belongs to the First World. This mix is epitomised by the rates of HBV infection in the two populations. Black Africans have very high exposure and carrier rates of the virus, whereas the white population has very low rates. Correspondingly, HBV related diseases are very common among black Africans but rare among white Africans. ${ }^{1}$ There is a great deal of urgency in instituting a comprehensive vaccination programme among the black population. With the disappearance of the policy of apartheid, the white population, with very little exposure to HBV previously, will now be mixing freely with a black population in which HBV infection is highly endemic and they too will benefit from the vaccination programme. A 'catch up' programme of vaccination could lessen the threat of infection in this context but, because of financial constraints, such a programme is not being contemplated.

\section{POSSIBILITIES FOR ERADICATION VERSUS}

\section{COMPREHENSIVE CONTROL}

Given the difficulties that were experienced in obtaining satisfactory levels of receipt of the second and especially the third dose of HBV vaccine in a rural area of Africa without intensive financial and logistic back up, ${ }^{23}$ it could be assumed that complete eradication of the virus is difficult to achieve and that the best that we could hope for in Africa is a reasonable level of control. However, the coverage in the routine vaccination schedule for BCG inoculation during the same period was $86 \%$ and that for polio $97-99 \% .{ }^{23}$ This achievement suggests that the inclusion of $\mathrm{HBV}$ vaccination in the Expanded Programme on Immunisation, 
perhaps by adding it to diphtheria, tetanus, and pertussis (DTP) as a tetravalent vaccine, should resolve the shortcomings shown in the Venda study. ${ }^{23}$

\section{IMPORTANCE OF HORIZONTAL VERSUS}

PERINATAL TRANSMISSION

In South Africa, urbanisation of black Africans has been accompanied by a substantial decline in HBV carriage. This unexpected bonus has been paralleled by a fall in the incidence of hepatocellular carcinoma. ${ }^{24}$ As shown from data obtained in Soweto, ${ }^{14}$ the decrease in the carrier rate starts with the first generation born in the urban environment. Black women born in Soweto have an adult $\mathrm{HBV}$ carrier rate of $1.3 \%$ compared with a carrier rate of $4.0 \%$ in women of the same age born in rural areas but moving to Soweto in late adolescence or early adulthood. A further decrease occurs with the next generation born in Soweto, as shown by the carrier rate in the daughters of these women, which is only $0.57 \% .^{10}$ Thus, within two generations born in an urban environment, HBV carriage decreases sixfold to sevenfold in the absence of a vaccination programme. This decrease is a product of the routes and timing of $\mathrm{HBV}$ infection in Africa and reflects in particular an escape from the 'hostile' environment of highly infectious young siblings and playmates.

This phenomenon raises the possibility that even though vaccination programmes in Africa are, with one or two exceptions, lagging behind those in the Far East, the high carrier rates in Africa may decrease relatively more quickly than those in the Far East when vaccination becomes universal. This may enable Africa to catch up with the Far East in eliminating the virus and its life threatening sequelae.

Kew MC. Chronic hepatitis B virus infection and hepatocellular carcinoma in Africa. $S$ Afr $\mathcal{F} S c i$ 1992; 88: 524-8.

2 Kulkarni AG, Aloowooja FO, Wayo GB. Prevalence of hepatitis B surface antigen in northern Nigerian blood donors. Vox Sang 1986; 50: 151-3.

3 Whittle HC, Bradley HK, McLauchan K, et al. Hepatitis B virus infection in two Gambian villages. Lancet 1983; virus inf.

4 Prozesky OW, Szmuness W, Stevens CE, et al. Baseline epidemiological studies for a hepatitis B vaccine trial in KaNgwane. S Afr Med f 1983; 64: 891-3.

5 Thursz MR, Kwiatowski D, Allsop CEM, Greenwood BM, Thomas HC, Hill AVS. Association between an MHC class II allele and clearance of the hepatitis $B$ virus in the Gambia. N Engl f Med 1995; 332: 1065-9.

6 Botha JF, Ritchie MJ, Dusheiko GM, Mouton HWK, Kew MC. Hepatitis B virus carrier state in black children in Ovamboland: role of perinatal and horizontal infection Lancet 1984; ii: 1210-2.

7 Dusheiko GM, Brink BA, Conradie JD, Marimuthu T, Sher $R$. Regional prevalence of hepatitis B, delta, and human immunodeficiency virus infection in southern Africa: A immunodeficiency virus infection in southern Africa: A large popul.

8 Ayoola EA. Viral hepatitis in Africa. In: Zuckerman AJ, ed. Viral hepatitis and liver disease. New York: Alan R Liss, 1988: 161-9.

9 Kew MC, Miller GB, Stevenson CM, Macnab GM, Bersohn I. The prevalence of virus-B hepatitis in South African blacks. $S$ Afr Med $\mathcal{f} 1974 ; 49: 1837-8$.

10 DiBisceglie AM, Kew MC, Dusheiko GM, et al. Prevalence of hepatitis B virus infection among black children in Soweto. BMF 1986; 292: 1440-2.

11 Coursaget P, Chiron JP, Barres JL, Barin F. Hepatitis B virus serological markers in Africans with liver cirrhosis and hepatocellular carcinoma. In: Williams AO, O'Cono GT, DeThe GB, Johnson CA, eds. Virus-associated cancers in Africa. Lyon: Scientific Publications, 1984: 199-211.

12 Bowry TR. Seroepidemiology of hepatitis B in an urban population of Nairobi, Kenya. $\mathcal{J}$ Infect Dis 1983; 148: populati
13 Vos GH, Rose EF, Marimuthu T. Hepatitis B antigen and antibodies in rural and urban southern African blacks. $S$ Afr $\mathcal{F}$ Med 1984; 57: 868-70.

14 Kew MC, Kassianides C, Berger EL, Song E, Dusheiko GM. Prevalence of chronic hepatitis B virus infection in pregnant women living in Soweto. $\mathcal{F}$ Med Virol 1987; 22: 263-8.

15 Barin F, Perrin J, Chotard J, et al. Cross-sectional and longitudinal epidemiology of hepatitis B in Senegal. Prog Med Virol 1981; 27: 148-62.

16 Stevens CE, Szmuness W. Vertical transmission of hepatitis $B$ and neonatal hepatitis B. In: Bianchi L, Gerok W, Sickinger $\mathrm{K}$, Stalder GA, eds. Virus and the liver. Lancaster, England: MTP Press, 1980: 285-92.

17 Song E, Kew MC, Hwang L-Y, Beasley RP. Epidemiology of hepatitis B virus infection in South African Chinese. Am $\mathcal{F}$ Epidemiol 1988; 128: 828-38.

18 Kew MC, Mackay ME, Mindel B, et al. Prevalence of hepatitis $\mathbf{B}$ surface antigen and antibody in white and black patients with diabetes mellitus. If Clin Microbiol 1976; 4: 467-9.

19 Kew MC, van Staden L, Pitcher L, et al. Prevalence of hepatitis B virus infection in coloured schoolchildren in Johannesburg. S Afr F Sci 1989; 85: 379-81.

20 Kew MC, Reis P, Macnab GM, Seftel HC, Bersohn I. The witch doctor and tribal scarification of the skin and the hepatitis B antigen. S Afr Med 7 1973; 47: 2419-20.

21 Schneider J, King L, Macnab GM, Kew MC. Hepatitis B surface antigen in black and white patients with venereal disease. Br $¥$ Vener Dis 1977; 32: 372-4.

22 Prozesky OW, Stevens CE, Szmuness W, et al. Immune response to hepatitis B vaccine in newborns. F Infect 1983, 7: $\$ 53-5$.

23 Schoub BD, Johnson S, McAnerney JM, et al. Integration of hepatitis $B$ vaccination into rural African primary health care programmes. BMF 1991; 303: 313-6.

24 Kew MC, Kassianides C, Hodkinson J, Coppin A, Paterson AC. Hepatocellular carcinoma in urban-born blacks: frequency and relation to hepatitis $\mathrm{B}$ virus infection. $B M \mathcal{F}$ 1986; 293: 1339-41.

25 Kew MC. Protective efficacy of hepatitis B vaccination. Lancet 1995; 345: 1065-6.

26 Cronberg S, Hansson B-G, Thermos M, Moestrup T, Sow MM. Hepatitis D (delta agent) in primary hepatocellular carcinoma and liver disease in Senegal. Liver 1984; 4, 275-9.

27 Greenfield C, Farci P, Osidiana V, et al. Hepatitis delta virus infection in Kenya. Am $\mathcal{F}$ Epidemiol 1986; 123: 416-23.

28 Tsega E, Mengesha B, Hansson B-G, Lindberg J, Nordenfeldt E. Hepatitis A, B, and delta infection in Ethiopia: A serological survey with demographic data. Am $\mathcal{F}$ Epidemiol 1985; 123: 344-51.

29 Kew MC, Hadziyannis SJ, Dusheiko GM, Paterson AC Does delta infection play a role in the pathogenesis of hepatitis B virus-related hepatocellular carcinoma? $B M \mathcal{Y}$ 1984; 288 : 1727 .

30 Kew MC, Houghton M, Choo Q-L, Kuo G. Hepatitis C virus antibodies in southern African blacks with hepatovirus antibodies in southern African blacks
cellular carcinoma. Lancet 1990; 335: 873-4.

31 Ellis LA, Brown D, Conradie JD, et al. Prevalence of hepatitis $\mathrm{C}$ in South Africa: detection of anti-HCV in recent and stored serum. F Med Virol 1990; 32: 249-51.

32 Coursaget P, Bourdil C, Kastally R, et al. Prevalence of hepatitis $\mathrm{C}$ virus infection in Africa: anti-HCV antibodies in the general population and in patients suffering from cirrhosis and primary liver cancer. Res Virol 1990; 141: 449-51.

33 Kamel MA, Ghaffar YA, Wasef MA, Wright M, Clark LC, Miller FD. High hepatitis C virus infection in Egyptian blood donors. Lancet 1992; 340: 427 .

34 El-Almady O, Halim A-B, Mansevu O, Sulman T. Incidence of hepatitis C virus in Egypt. $\mathcal{F}$ Hepatol 1994; 21: 687 .

35 Bukh J, Miller RH, Kew MC, Purcell RH. Hepatitis C virus RNA in southern African blacks with hepatocellular carcinoma. Proc Natl Acad Sci USA 1993; 90: 1848-51.

36 Davidson F, Simmonds P, Ferguson JP, et al. A survey of major genotypes of hepatitis $C$ virus using restriction fragment length polymorphisms of sequences amplified from the 5 ' non-coding region. $\mathcal{F}$ Gen Virol 1995; 76: 1197-204.

37 Dusheiko GM, Bowyer SM, Sjogren MH, Ritchie MJ, Santos AP, Kew MC. Replication of hepatitis B virus in adult carriers in an endemic area. $\mathcal{F}$ Infect Dis 1985; 152: adult car

38 Song E, Dusheiko GM, Bowyer S, Kew MC. Hepatitis B virus replication in southern African blacks with hepatitis $B$ virus surface antigen positive hepatocellular carcinoma. Hepatology 1984; 4: 608-10.

39 Tur-Kaspa R, Klein A, Aharonson S. Hepatitis B virus precore mutants are identical in carriers from various ethnic origins and are associated with a range of liver diseases. Hepatology 1992; 16: 1338-42.

\section{Discussion}

Gust: Might the difference in carrier rates between women born in Soweto and the Soweto school girls exist because the school girls have not yet been exposed to infection through sexual activity? It may be that, over the 
next five years or so, their carrier rate will approach that found in their mothers.

Kew: That may be partly true. In fact, the Soweto school girls vary in age from very young to as much as 19 years of age. In Soweto, sexual activity usually starts around the age of 15 , so this group would include many who are already exposed to this risk. I think their carrier rate may increase slightly over the next five years but probably not very significantly.

Kiire: In the context of the Venda vaccine study, you commented that in rural situations it was difficult to achieve high levels of coverage, particularly for the second and third dosage. How much health education was carried out before the introduction of this programme and who carried it out? It may be that, at the time the study was done, the population was hostile to the government, which may have had an adverse effect on vaccine utilisation. Prior to independence in Zimbabwe, for example, when the government tried to promote the use of condoms, people refused, saying it was aimed at keeping the African population down. When the same programme was carried out after independence, it was largely accepted.

Also, it may be that timing of the vaccination doses has an important impact on compliance.
In Kenya, for example, we are giving the hepatitis B vaccine at intervals of 6,10 and 14 months, and the coverage rate for the third vaccine dose is about $75 \%$. This may be because the third dose is fairly close to the first and second doses.

Kew: Venda was actually chosen for this study because it had the right number of people and because it seemed to have the best public health setup. That is, the existing staff structure seemed best equipped both to carry out an education programme and to deliver the vaccine. The vaccine was provided free but there was no extra money actually to carry out the study, which had to be done within the existing framework, so this was truly a test of field conditions in Africa. Clearly, our education programme was not good enough and there was a high drop off rate. It should be said, however, that the coverage for the EPI vaccines at the same time was very good $-86 \%$ for BCG and $97-99 \%$ for polio. Apparently, it was not that they felt that the government was trying to poison them, but rather it was a problem of adding three extra injections that were not part of the EPI. For hepatitis B vaccination to succeed in Africa at the present time, it has to become part of the EPI. 